\title{
PENGARUH KUALITAS PRODUK, HARGA, DAN KUALITAS LAYANAN TERHADAP KEPUASAN KONSUMEN DI ELLADERMA SKIN CARE MALANG
}

\author{
*(Puguh Cahyono \\ Fakultas Ekonomi Universitas Islam Lamongan \\ Puguhcahyono41@gmail.com
}

\begin{abstract}
Abstrak: Perkembangan masyarakat serta aktivitas masyarakat yang tinggi terutama diwilayah perkotaan untuk saat ini menyebabkan parapelaku bisnis memanfaatkan peluang tersebut dengan mendirikan berbagai macam bisnis baru sebagai alternatife bagi para konsumennya. Salah satu sector yang menjadi trend dikalangan wanita khususnya, yaitu berkembangnya berbagai macam klinik kecantikan yang menawarkan berbagai macam perawatan, baik untuk jasa perawatan maupun produk perawatan kulit, sehingga pelaku bisnis memanfaatkan hal tersebut dengan mendirikan klinik kecantikan, pelaku bisnis melakukan berbagai cara untuk menarik konsumen mau membeli produk dan melakukan tindakan pelayanan yang ditawarkan pesaing. Penelitian ini bertujuan untuk menganalisis seberapa besar pengaruh kualitas produk terhadap kepuasan konsumen, harga terhadap kepuasan konsumen, dan kualiatas layanan terhadap kepuasan konsumen secara parsial dan pengaruh kualitas produk, harga dan kualitas layanan secara simultan terhadap kepuasan konsumen Penelitian ini menggunakan penelitian asosiatif tipe kausal sebab akibat sebab akibat populasi dalam penelitian ini adalah konsumen Elladerma Skin Care Malang sebanyak 150, sampel penelitian sebanyak 100 konsumen diambil secara simple random sampling. Analisa data menggunakan regresi linier berganda. Hasil penelitian secara parsial di dapat kualitas produk t-hitung sebesar 2,67 terhadap kepuasan konsumen, harga t-hitung 2,425 terhadap kepuasan konsumen dan kualitas layanan dengan t-hitung 4,061 terhadap kepuasan konsumen, menunjukkan masing-masing variabel berpengaruh terhadap kepuasan konsumen. Kualitas layanan berpengaruh yang dominan 4,061 dibandingkan kualitas produk dan harga dan secara simultan F hitung sebesar 35,483 menunjukkan bahwa kualitas produk, harga dan kualitas layanan secara bersama-sama berpengaruh terhadap kepuasan konsumen pada klinik Elladerma Skin care..
\end{abstract}

Kata Kunci: Produk, Harga, Layanan, Kepuasan konsumen dan klinik kecantikan. 


\section{PENDAHULUAN}

Perkembangan masyarakat serta aktivitas masyarakat yang tinggi terutama diwilayah perkotaan untuk saat ini menyebabkan para pelaku bisnis memanfaatkan peluang tersebut dengan mendirikan berbagai macam terobosanterobosan bisnis baru sebagai alternative bagi para konsumennya. Salah satu sektor yang menjadi trend di kalangan wanita khususnya, yaitu menjamurnya berbagai macam klinik kecantikan yang menawarkan berbagai macam perawatan, baik untuk jasa maupun produk perawatan kulit Salah satu contoh dari pesatnya persaingan bisnis klinik kecantikan dapat dilihat pada klinik Elladerma Skin Care. Klinik kecantikan yang berlokasi di kota Malang, Jawa Timur yang merupakan kota pariwisata ini telah berdiri semenjak tahun2012 lalu. Sebagai salah satu pelaku bisnis yang memiliki trend permintaan yang selalu meningkat setiap tahunnya menjadikan klinik kencantikan Elladerma Skin Care harus melakukan pembaharuan serta terobosan-terobosan baru untuk selalu menjaga kepercayaan dari konsumennya. Maka dari itu menganalisa pengaruh dari faktor-faktor pendukung kepuasan konsumen mutlak diperlukan sebagai salah satu cara efektif memperbaiki perkembangan bisnis kedepannya. Salah satu faktor yang peneliti anggap berpengaruh terhadap kepuasan konsumen adalah kualitas produk harga, dan kualitas layanan. Maka dari itu penulis tertarik untuk mengambil judul tentang "Pengaruh Kualitas Produk, Harga, dan Kualitas Layanan Terhadap Kepuasan Konsumen Di Elladerma Skin Care Malang”

Rumusan Masalah yang ada dalam penelitian ini adalah sebaga berikut:
1. Bagaimana pengaruh kualitas produk terhadap kepuasaan konsumen di Elladerma Skin Care Malang?

2. Bagaimana pengaruh harga terhadap kepuasaan konsumen di Elladerma Skin Care Malang?

3. Bagaimana pengaruh kualitas layanan terhadap kepuasaan konsumen di Elladerma Skin Care Malang?

4. Bagaimana pengaruh antara kualitas produk,hargadan kualitas layanan terhadap kepuasaan konsumen di Elladerma Skin Care Malang?

\section{Konsumen}

Pengertian konsumen menurut Kotler adalah semua individu dan rumah tangga yang membeli atau memperoleh barang atau jasa untuk dikonsumsi pribadi. Kesimpulan pengertian konsumen dari teori diatas adalah setiap orang pemakaian barang dan jasa yang tersedia dalam masyarakat, baik bagi kepentingan diri sendiri, keluarga, orang lain dan tidak untuk diperdagangkan.

\section{Kepuasan Konsumen}

Menurut Normasari dkk menyatakan konsumen merupakan respon atau penilaian konsumen terhadap kineja barang atau jasa yang mereka konsumsi dimana hasil yang diterima itu paling tidak harus sama dengan harapan konsumen. terdapat tiga Terdapat tiga dimensi dalam mengukur kepuasan pelanggan secara universal menurut Arifin, 2006, yaitu: Attributes related to product; Attributes related to servic; Attributes related to purchase. eJournal. Volume 05 Nomer 01 Tahun 2016, Edisi Yudisium Periode Juli 2016, hal 23-28 


\section{Kualitas Produk}

Menurut Kotler dan Amstrong (2009:283), mengungkapkan bahwa kualitas produk merupakan kemampuan sebuah produkdalam memperagakan fungsinya, hal itu termasuk keseluruhan durabilitas, reliabilitas, ketepatan, kemudahan pengoperasian dan reparasi produk juga atribut produk lainnya.

\section{Harga}

Menurut Gitosudarmo (2000: 228),yang mendefinisikan harga sebagai sejumlah uang yang dibutuhkan untuk mendapatkan sejumlah barang beserta jasa-jasa tertentu atau kombinasi dari keduanya.Prosedur Penetapan Harga menurut Irawan (2010) yaitu Memilih Sasaran Penetapan Harga; Menentukan Permintaan; Mengitimasi Biaya; Menganalisa Harga dan Tawaran Pesaing; Memilih Harga Akhir.

\section{Kualitas Layanan}

Tjiptono (2011:331), mengungkapka nbahwa kualitas jasa merupakan upaya pemenuhan kebutuhan dan keinginan konsumen serta ketepatan penyampaiannya dalam mengimbangi harapan konsumen. Dimensi kualitas Layanan menurut Khan dan Tabassum (2010) yaitu Reliability, Responsiveness, Assurance, Empathy, Tangibles.

\section{HASIL PEMBAHASAN}

\section{Karakteristik Responden}

Model regresi yang diperoleh berdasarkan hasil penelitian dapat dituliskan dalam bentuk persamaan sebagai berikut:

$\mathrm{Y}=0,044+0,147 \mathrm{X} 1+0,174 \mathrm{X} 2+$ $0,253 \mathrm{X} 3$

Berdasarkan persamaan tersebut ketiga variabel bebas memiliki koefisien regresi kearah positif. hal ini berarti semakin baik kualitas produk, harga, dan kualitas layanan, maka semakin baik kepuasan konsumen. hasil uji $\mathrm{F}$ menunjukkan nilai sebesar 35,483 dengan tingkat signifikansi 0,000 kurang dari 5\%, hal ini berarti bahwa pengaruh kualitas produk, harga, dan kualitas layanan secara bersama-sama berpengaruh signifikan pada kepuasan konsumen.

\section{METODE}

Jenis penelitian ini adalah penelitian deskriptif kuantitatif dengan bentuk rumusan masalah asosiatif tipe kausal (sebab-akibat). Variabel yang terdapat dalam penelitian yaitu tentang kualitas produk (X1), harga (X2), kualitas layanan (X3) dan kepuasaan konsumen (Y). Populasi dalam penelitian ini adalah responden klinik sejumlah 150 responden. Jumlah sampel 100 responden ditentukan dengan menggunakan teknik simple random samplin.

Data dikumpulkan dengan menggunakan angket, wawancara serta dokumentasi. Angket disusun berdasarkan variabel penelitian dengan skala pengukuran instrumen menggunakan skala likert. Teknik analisis data menggunakan regresi linier berganda dengan kriteria uji $F$ dan Uji t. Uji $F$ digunakan untuk menguji signifikansi variabel kualitas produk, harga, dan kualitas layanan terhadap kepuasan konsumen. sedangkan uji $t$ digunakan untuk menguji signifikansi pengaruh kualitas produk, harga, dan kualitas layanan terhadap kepuasan konsumen secara parsial.

Koefisien determinasi (R-Square) yang dihasilkan dalam penelitian ini sebesar 0.526 menunjukkan bahwa kualitas produk $\left(\mathrm{X}_{1}\right)$, harga $\left(\mathrm{X}_{2}\right)$, dan kualitas layanan $\left(\mathrm{X}_{3}\right)$ bberpengaruh terhadap kepuasan konsumen sebesar 52,6\% sedangkan sisanya $47,4 \%$ dipengaruhi oleh faktor-faktor lain selain variabel dalam penelitian ini. Hasil uji $t$ menunjukkan semua variabel mempunyai pengaruh signifikan. Nilai $t$ hitung pada variabel pengaruh kualitas produk(X1) sebesar e- Journal. Volume 05 Nomer 01 Tahun 2016, Edisi Yudisium Periode Juli 2016, hal 23-28 26 
2.678 dengan tingkat signifikan 0.009, harga (X2) sebesar 2.425 dengan tingkat signifikansi 0.017, kualitas layanan (X3) sebesar 4.061 dengan tingkat signifikansi 0.000. Dengan tingkat signifikansi kurang dari $5 \%$

\section{Pembahasan \\ Pengaruh Kualitas Produk Terhadap Kepuasan Konsumen}

Secara garis besar pengaruh kualitas produk sangat berpengaruh terhadap kepuasan konsumen di klinik Elladerma Skin Care. Berdasarkan hasil analisis diperoleh hasil bahwa pengaruh kualitas produk secara parsial berpengaruh signifikan terhadap kepuasan konsumen. hal ini didasarkan pada hasil t-hitung yaitu sebesar 2,678 dan signifikansinya kurang dari 5\% yaitu 0,009. Hasil tersebut membuktikan bahwa semakin tinggi kualitas produk, semakin tinggi pula kepuasan konsumen.

Hasil penelitian ini mendukung teori dan hasil penelitian sebelumnya, diantaranya dari Kotler dan Amstrong (2009:283), mengungkapkan bahwa kualitas produk merupakan kemampuan sebuah produk dalam memperagakan fungsinya, hal itu termasuk keseluruhan durabilitas, reliabilitas, ketepatan kemudahan pengoperasian dan reparasi produk juga atribut lainnya dan kepuasan konsumen.Ditinjau dari penelitian Tri Kunantyas (2007) bahwa kualitas produk berpengaruh secara parsial terhadap kepuasan konsumen, maka kualitas produk sering kali dijadikan sebagai pertimbangan didalam pengambilan keputusan pembelian, konsumen berani mengeluarkan biaya yang cukup mahal untuk membeli asalkan dengan kualitas yang terjamin.

Berdasarkan uraian tersebut dapat disimpulkan bahwa dalam penelitian ini pengaruh kualitas produk terbukti menjadi faktor yang mempengaruhi kepuasan konsumen di Elladerma Skin Care. Dengan memiliki kualitas produk yang baik maka kepuasan konsumen semakin meningkat

\section{Pengaruh Harga Terhadap Kepuasan Konsumen}

menunjukkan bahwa pengaruh kualitas produk, harga, dan kualitas layanan berpengaruh signifikan pada kepuasan konsumen.

Secara garis besar pengaruh harga sangat berpengaruh terhadap kepuasan konsumen di klinik Elladerma Skin Care. Berdasarkan hasil analisis diperoleh hasil bahwa pengaruh harga secara parsial berpengaruh signifikan terhadap kepuasan konsumen. Hal ini didasarkan pada hasil t-hitung yaitu sebesar 2,425 dan signifikansinya kurang dari 5\% yaitu 0,017. Hasil tersebut membuktikan bahwa semakin tinggi harga, maka kepuasan konsumen akan mengalami peningkatan secara nyata

Hasil penelitian ini mendukung teori dan hasil penelitian sebelumnya, diantaranya dari Kotler dan Amstrong (2012: 439) mengemukakan bahwa harga merupakan sejumlah uang yang dibebankan atas suatu produk atau jasa, atau jumlah dari nilai yang ditukarkan konsumen atas manfaat-manfaat karena memiliki atau menggunakan produk atau jasa.Ditinjau dari penelitian Tri Kunantyas (2007) bahwa harga berpengaruh secara parsial terhadap kepuasan konsumen. Harga sebagai alat ukur dalam melakukan pembelian, konsumen akan menilai apa yang sudah dibayar dengan manfaat yang diperoleh dari produk beserta pelayannya. Pertimbangan tersebut didasarkan pada seberapa besar kemampuan konsumen dalam membeli produk, sehingga konsumen mengingatkan harga yang terjangkau namun produk yang dirasakan memberikan manfaat yang sesuai dengan apa yang diinginkan.

Berdasarkan uraian tersebut dapat disimpulkan bahwa dalam penelitian ini pengaruh harga terbukti menjadi faktor yang mempengaruhi kepuasan 


\section{Pengaruh Kualitas Layanan Terhadap Kepuasan Konsumen}

Secara garis besar pengaruh kualitas layanan sangat berpengaruh terhadap kepuasan konsumen di klinik Elladerma Skin Care. Berdasarkan hasil analisis diperoleh hasil bahwa pengaruh kualitas layanan secara parsial berpengaruh signifikan terhadap kepuasan konsumen. Hal ini didasarkan pada hasil t-hitung yaitu sebesar 4,061 dan signifikansinya kurang dari 5\% yaitu 0,000. Hasil tersebut membuktikan bahwa semakin tinggi kualitas layanan, maka kepuasan konsumen akan mengalami peningkatan secara nyata.

Hasil penelitian ini mendukung teori dan hasil penelitian sebelumnya, diantaranya dari Tjiptono (2011:331), mengungkapkan bahwa kualitas jasa merupakan upaya pemenuhan kebutuhan dan keinginan konsumen serta ketepatan penyampaiannya dalam mengimbangi harapan konsumen.Ditinjau dari penelitian Tri Kunantyas (2007) bahwa kualitas layanan merupakan variabel yang mempunyai pengaruh yang dominan terhadap kepuasan konsumen. Hal ini dikarenakan ketika responden menjadi pertimbangan utama yaitu kondisi ruangan, penampilan, karyawan, dan fasilitas penunjang lainnya.

Berdasarkan uraian tersebut dapat disimpulkan bahwa dalam penelitian ini pengaruh kualitas layanan terbukti menjadi faktor yang mempengaruhi kepuasan konsumen.

Pengaruh Kualitas Produk, Harga, dan Kualitas Layanan Terhadap Kepuasan Konsumen

Berdasarkan hasil uji secara simultan menunjukan bahwa kualitas produk, harga, dan kualitas layanan secara simultan atau bersama-sama

\section{PENUTUP}

\section{Simpulan}

1. Terhadap pengaruh kualitas produk terhadap kepuasan konsumen

2. Terdapat pengaruh kualitas harga terhadap kepuasan konsumen

3. Terdapat pengaruh kualitas layanan terhadap kepuasan konsumen e- Journal. berpengaruh signifikan pada kepuasan konsumen. hal ini didasarkan pada hasil penelitian yang dapat dilihat dari $\mathrm{F}$ hitung sebesar 35,483 dan signifikansinya kurang dari $5 \%$ yaitu 0,000. Hasil tersebut membuktikan bahwa semakin tinggi kualitas produk, harga, dan kualitas layanan, maka kepuasan konsumen akan mengalami peningkatan secara nyata. Besarnya pengaruh kualitasproduk, harga, dan kualitas layanan sebesar $51,1 \%$ sedangkan 48,9\% dipengaruhi oleh faktor-faktor lain selain variabel dalam penelitian ini.

Secara garis besar, pengaruh kualitas produk, harga, dan kualitas layanan yang paling dominan dalam kepuasan konsumen adalah kualitas layanan karena memiliki nilai koefisien beta dan t-hitung paling besar.Hasil penelitian ini mendukung teori dan hasil penelitian sebelumnya, diantaranya yang dilakukan oleh Tri Kuntaningtyas (2007) yang menerangkan bahwa kualitas produk, harga, dan kualitas layanan merupakan faktor yang penting yang dipertimbangkan oleh kepuasan konsumen. hal ini diperkuat oleh penelitian sebelumnya yang telah dilakukan oleh Mulyono, dkk (2007), Normasari, dkk (2013), Ari Prasetio (2012),

Sehingga, dapat disimpulkan bahwa pengaruh kualitas produk, harga, dan kualitas layanan secara simultan berpengaruh signifikan pada kepuasan konsumen di Elladerma Skin Care. Berdasarkan hasil uji secara parsial diantar variabel-variabel tersebut yang paling dominan berpengaruh pada kepuasan konsumen adalah variabel kualitas layanan.

Volume 05 Nomer 01 Tahun 2016, Edisi Yudisium Periode Juli 2016, hal 23-28 28 
4. Terdapat pengaruh kualitas produk, harga, dan kualitas layanan terhadap kepuasan konsumen

\section{Saran}

1.Diharapkan pihak perusahaan dapat mempertahankan serta meningkatkan mutu dari Kualitas. Layanan, karena variabel kualitas layanan mempunyai pengaruh yang dominan dalam mempengaruhi Kepuasan konsumen, diantaranya yaitu dengan meningkatkan mutu beauty terapis dan seringnya mengadakan diskon, sehingga kepuasan konsumen akan meningkat.

2. Mengingat variabel bebas dalam penelitian ini merupakan hal yang sangat penting dalam mempengaruhi kepuasan konsumen diharapkan hasil penelitian ini dapat dipakai sebagai acuan bagi peneliti selanjutnya untuk mengembangkan penelitian ini dengan mempertimbangkan variabel-variabel yang sudah masuk dalam penelitian ini.

\section{DAFTAR PUSTAKA}

Arifin.2006. Manajemen Pemasaran dan Pemasaran Jasa. Edisi Revisi. Bandung: Alfabeta

Ari Prasetyo 2012. Analisis Pengaruh Pelayanandan HargaTerhadap Kepuasan Pelanggan. Skripsi tidak diterbitkan. Surabaya: PPs Universitas Negeri Surabaya

Gitosudarmo.2000.Manajemen. Jilid 2.ED 7. Jakarta: Erlangga

Irawan, Hadi.2010. Manajemen Harga.Yogyakarta

Khan, Parisa Islam dan Tabassum, Ayesha. 2010. Service Quality and Customer Satisfaction of the Beauty-Care Service Industry in Dhaka: A Study on High-End Women's Parlors. The Journal of Business in Developing Nations (Online), vol. 12, No.11, (http://google.com,

diakses November 2015).

Kotler, Armstrong. 2012. Manajemen Pemasaran. Edisi ke tiga belas Terjemahan. Jakarta:Erlangga

Kotler, Philip dan Armstrong, Gary. 2009. Dasar-Dasar Pemasaran. Jilid 1. Terjemahan oleh A. Sindoro. Jakarta: Prenhallindo

Mulyono, dkk. 2007. Analisis Pengaruh Kualitas Produk dan Kualitas Layanan terhadap Kepuasan Konsumen. Jurnal Studi Manajemen \& Organisasi (Online), Vol. 4, No.2, Hal. (http://ejournal.undip.ac.id/index.ph p/smo, diakses Oktober 2015)

Normasari, dkk. 2013. Pengaruh Kualitas Pelayanan terhadap Kepuasan Pelanggan, Citra Perusahaan dan Loyalitas Pelanggan. Jurnal Administrasi Bisnis (Online) , Vol. 6, No. 2, (http://google.com, diakses November 2015)

Tjiptono, Fandy. 2011. Pemasaran Jasa. Malang: Bayumedia Publishing

Tri Kunantyas. 2007. Pengaruh Kualitas Produk, Harga, dan Kualitas Layanan Terhadap Kepuasan Konsumen. Skripsi tidak diterbitkan. Surabaya: PPs Universitas Negeri Surabaya. 